\title{
PERAN GEN AIMI DAN INTENSITAS CAHAYA TERHADAP KARAKTER POLA PIGMEN IKAN BADUT HITAM (Amphiprion percula)
}

\author{
Daniar Kusumawati"), S. Permana*"), Ketut Maha Setiawati"), dan Haryanti") \\ *) Balai Besar Penelitian dan Pengembangan Budidaya Laut \\ J. Br. Gondol Kec. Gerokgak Kab. Buleleng, Kotak Pos 140, Singaraja-Bali 81101 \\ E-mail: ornamental_research@yahoo.co.id \\ ${ }^{* *}$ Fakultas MIPA-Biologi, Universitas Brawijaya, Malang \\ Jl. Veteran, Malang 65145
}

(Naskah diterima: 9 Desember 2011; Disetujui publikasi: 8 Mei 2012)

\begin{abstract}
ABSTRAK
Pola pigmen merupakan faktor utama yang menentukan tingginya kualitas ikan hias. Pada benih-benih F1 populasi budidaya ikan badut hitam (Amphiprion percula) diketahui mengalami degeneratif pola pigmen yang menyimpang dibandingkan dengan populasi di alam. Pola pigmen merupakan salah satu karakter fenotip yang diturunkan di mana ekspresinya bergantung pada interaksi genetik dengan faktor eksternal yaitu lingkungan. Tujuan dari penelitian ini adalah untuk mengkaji peran gen yaitu Aim 1 yang mengontrol sintesis melanin dan kondisi lingkungan dalam menginduksi pola pigmen hitam ikan badut hitam (Amphiprion percula). Analisis gen Aiml dilakukan dengan menggunakan program speedy PCR dilanjutkan dengan SSCP (single strand confirmation polymorphism) untuk mengidentifikasi variasi genetik dari gen Aiml. Analisis SDS Page dilakukan untuk mengetahui peranan lingkungan terhadap profil protein yang disintesis. Berdasarkan hasil penelitian diketahui bahwa primer Aim 1 memiliki sisi pengenalan pada whole genom ikan badut hitam (Amphiprion percula) pada target sequence $45 \mathrm{bp}$. Berdasarkan analisis SSCP profil fragmentasi amplicon primer Aiml pada masing-masing tingkatan pada populasi budidaya homolog dengan populasi alam, sehingga gen Aim 1 bukan merupakan gen yang mengontrol fenomena degeneratif pola pigmen ikan badut hitam (Amphiprion percula). Peran lingkungan yaitu cahaya memberikan pengaruh positif dalam menginduksi pola pigmen melalui stimulus pada sistem neuron dan migrasi melanophore.
\end{abstract}

KATA KUNCl: Amphiprion percula, degeneratif pola pigmen, gen Aim1, intensitas cahaya

ABSTRACTS: The role of Aiml gene and light intensity for the character of pigment pattern of black clown fish (Amphiprion percula). By: Daniar Kusumawati, S. Permana, Ketut Maha Setiawati, and Haryanti

Pigment pattern is the main factor to determine the high quality of ornamental fish. On the seeds of cultured populations of Fl black clown fish (Amphiprion percula) shows degenerative of pigment pattern from that of the wild type. The pigment pattern is one of the characters-derived phenotypes that the expression is depends on interaction between genetic and environment as external factor. The purpose of this research were to examine the role of Aiml gene that control the synthesis of 
melanin and condition of environment in inducing black pigment pattern of black clown fish (Amphiprion percula). Aim 1 gene analysis was performed using speedy PCR programme and continued with SSCP (single strand confirmation polymorphism) to identify the genetic variations of Aiml gene. Analysis SDS Page was conducted to determine the role of the environment against a protein that is synthesized. Based on this research, primer Aim 1 has amplified the whole genom of black clown fish on sequence $45 \mathrm{bp}$. Based on the pattern of the fragmentation amplicon primer Aim 1 from SSCP analysis, each grade of cultured population and wild type population was homolog. So that, AIMI gene was not control the existence of degenerative pattern pigment black clown fish (Amphiprion percula). The environment that was light induces a positive influence in the pigment pattern through the stimulus on neuron system and melanophore migration.

\section{KEYWORDS: Amphiprion percula, degenerative of pigment pattern, Aim 1 gene, light intensity}

\section{PENDAHULUAN}

Ikan hias air laut memiliki bervariasi pola warna yang sangat indah dan cerah. Pola warna pada ikan sangat penting perannya sebagai pemilihan pasangan (Gonzales \& Uy, 2009), indikator pemijahan, alat pertahanan dari musuh (kamuflase), perlindungan terhadap cahaya matahari, termoregulasi (Karlsson, 2001; Korzan et al., 2008) dan sekaligus merupakan faktor utama yang menentukan tingginya kualitas ikan tersebut (Gouveia et al., 2003). Ikan badut hitam (Amphiprion percula) yang ditemukan di perairan laut memiliki performansi yang sangat menarik dengan warna dasar kuning dan 3 ban putih pada bagian kepala, badan, dan pangkal ekor serta warna hitam pada bagian anterior dorsal yang menjadi ciri khasnya. Berbeda pada ikan badut hitam hasil budidaya, banyak mengalami degeneratif pola pigmen (Gambar 1) di mana pola pigmen hitam dan ban putih pada bagian badan dan pangkal ekor sering kali tidak muncul secara sempurna. Permulaan perkembangan pigmen telah terjadi pada saat embrio dengan munculnya melanocyte (melanisasi) di sekitar ekor, kepala dan pada kuning telur. Setelah 30 hari pemeliharaan, pola warna benih muncul dengan warna kuning-oranye dan 1 ban putih di bagian kepala, namun perkembangan pola warna hingga muncul 3 ban putih secara lengkap dengan warna hitam di sepanjang sisi badan masih tidak stabil. Ikan badut hitam hasil budidaya mengalami degenaratif warna apabila dibandingkan dengan ikan badut yang berasal dari alam, di mana pola ban putih tidak muncul secara sempurna dan beberapa individu berwarna lebih pucat tanpa ada warna hitam sebagaimana ciri khas dari spesies Amphiprion percula.
Pola pigmen merupakan salah satu karakter fenotip yang diturunkan dari induk pada turunannya. Hal ini menunjukkan bahwa pola pigmen yang muncul dikontrol secara genetik yang dikode oleh suatu gen yang memiliki susunan nukleotida interspesifik yang sesuai terhadap pola pigmen yang terbentuk (Sugie et al., 2004). Namun demikian ekspresi pola pigmen (fenotip) yang terbentukselalu akan bergantung pada interaksi faktor eksternal (lingkungan, pakan) dan internal (genetik). Adanya perubahan pola warna yang berbeda antara induk dan turunannya dimungkinkan adanya penyimpangan genetis sebagai akibat tekanan eksternal (lingkungan) sehingga sifat fenotip pada pola warna yang diturunkan mengalami perubahan. Banyak gen yang bertanggung jawab dalam pembentukan suatu pola pigmen yang sangat tergantung dari jenis spesiesnya (Hofreiter \& Schöneberg, 2010; Kelsh et al., 1996; Odenthal et al., 1996). Salah satu gen yang berperan dalam mengontrol sintesis melanin adalah gen Aiml dan mutasi pada gen Aim 1 diketahui menunjukkan hipopigmentasi dengan berbagai variasi fenotip (Sugie et al., 2004). Mengingat benihbenih $\mathrm{F} 1$ hasil budidaya yang banyak mengalami degeneratif pada warna hitam di bagian kedua sisi posterior anterior badan, sangat penting mengkaji peranan gen Aim 1 sebagai gen yang diduga bertanggung jawab dalam sintesis melanin pada ikan badut hitam.

Selain faktor gen sebagai pengontrol pola pigmen, faktor eksternal yaitu lingkungan juga mempengaruhi fisiologi sel pigmen yang mendorong perubahan formasi pola pigmen yang muncul. Secara alami, hewan memiliki kemampuan secara cepat untuk merubah pola pigmen sebagai respons stimuli dari lingkungan seperti warna lingkungan habitat hidup 

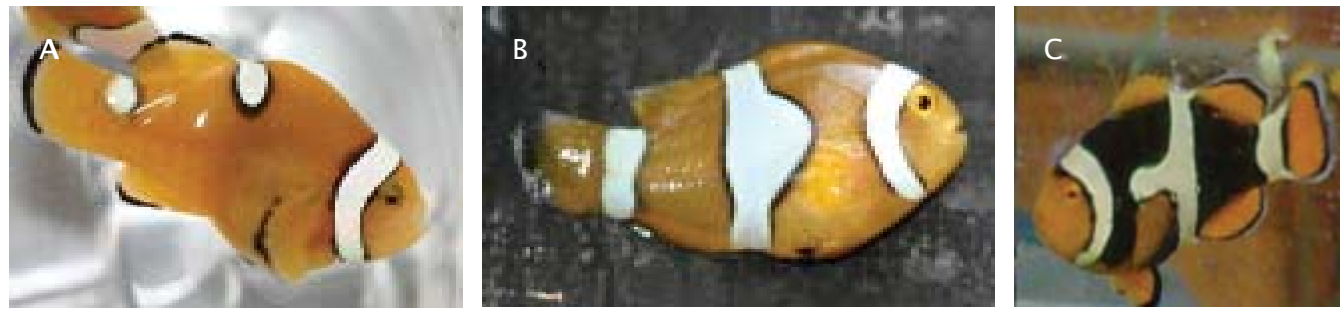

Gambar 1. Pola pigmen ikan badut hitam Amphiprion percula populasi budidaya (A-B) dan alam (C)

Figure 1. Pigment pattern of culture population of black clown fish Amphiprion percula (A-B) and wild population (C)

maupun intensitas cahaya (Nery \& Castrucci, 1997; Karlsson, 2001). Stimuli dari faktor lingkungan akan memberikan sinyal spesifik aktivator-inhibitor (Kelsh, 2004) yang akan diterima oleh sel syaraf yang akan mengaktivasi mekanisme downstream-nya sehingga menyebabkan perubahan distribusi (migrasi) (Kelsh, 2004) dan jumlah sel pigmen sistem integumen (Sugie et al., 2004). Mengingat begitu penting peran gen dan lingkungan terhadap pembentukkan karakter fenotip pola pigmen, maka dilakukan penelitian yang bertujuan untuk mengkaji peran gen Aim 1 serta peran faktor lingkungan dalam menginduksi pola pigmen hitam ikan badut hitam (Amphiprion percula).

\section{BAHAN DAN METODE}

\section{Eksperimen I}

\section{Sampel}

Pada eksperimen pertama, dilakukan kajian terhadap gen Aim 1 pada DNA ikan badut hitam (Amphiprion percula). Sampel uji yang digunakan adalah benih-benih $\mathrm{F} 1$ hasil budidaya umur 4-5 bulan yang dipelihara selama 3 bulan di lingkungan outdoor dengan wadah jaring ukuran $100 \mathrm{~cm} \times 100 \mathrm{~cm} \times 150 \mathrm{~cm}$ dan sepasang induk jantan dan betina yang merupakan hasil tangkapan di alam (populasi alam) yang dipelihara dalam akuarium ukuran $60 \mathrm{~cm} \times 40 \mathrm{~cm} \times 30 \mathrm{~cm}$. Pemeliharaan benih maupun induk dilakukan dengan sistem air mengalir. Sampel populasi budidaya yang telah dipelihara diambil 2-3 ekor yang dikelompokkan berdasarkan 5 tingkatan pola pigmen yang ditemukan (Tabel 1). Organ sampel yang digunakan pada populasi budidaya adalah daging sedangkan pada populasi alam adalah sirip yang dimaksudkan untuk mempertahankan kehidupan induk.

\section{Ekstraksi DNA}

Ekstraksi DNA dilakukan dengan menggunakan QIAamp DNA Mini Kit (50) (USA). Amplifikasi dilakukan pada whole genom menggunakan sequence gen Aim 1 yang homolog pada ikan-ikan cichlid (F : 5'-TGC CCC AGA GTC TGT ACA GCT TG-3', R : 5'- GCT GAT CAA CCA CAC CAA GCT GTA-3') dengan program Speedy PCR. Optimasi PCR yang digunakan adalah sebagai berikut: initial denaturasi $95^{\circ} \mathrm{C}$ selama 120 detik, 1 siklus; denaturasi $95^{\circ} \mathrm{C}$ selama 10 detik, 40 siklus; annealing pada suhu $67^{\circ} \mathrm{C}$ selama 10 detik, 40 siklus; ekstension $72^{\circ} \mathrm{C}$ selama 20 detik, 40 siklus dan final ekstension $72^{\circ} \mathrm{C}$ selama 180 detik, 1 siklus. Hasil amplifikasi dikonfirmasi menggunakan $2 \%$ agarose dalam $0,5 X$ SB buffer. Untuk melihat polimorfisme hasil amplifikasi, dilakukan analisis SSCP di mana hasil PCR pada masing-masing sampel pada tiap-tiap populasi di elektroforesis dengan menggunakan gel poliacrilamid Genegel Clean Excel 15/24 Kit, dengan fragmentasi gen yang dikondisikan pada suhu $15^{\circ} \mathrm{C}$ pada $\mathrm{P} 1=200 \mathrm{~V}, 12 \mathrm{~mA}, 3 \mathrm{~W}, 10$ menit dan $\mathrm{P} 2=600 \mathrm{~V}, 15 \mathrm{~mA}, 10 \mathrm{~W}, 30-40$ menit. Selanjutnya konfirmasi pita DNA pada hasil SSCP di-staining dengan menggunakan DNA silver staining kit.

\section{Eksperimen II}

\section{Sampel}

Pada eksperimen ini, dilakukan pengkajian peran lingkungan terhadap profil protein berdasarkan karakter fenotip yang muncul. Sampel yang digunakan adalah benih F1 populasi budidaya umur 4-5 bulan yang dipelihara selama 3 bulan dengan 2 kondisi berbeda yaitu indoor pada wadah bak polikarbonat kapasitas 500 liter dan outdoor 
Tabel 1. Tingkatan pola pigmen pada populasi budidaya ikan badut hitam (Amphiprion percula)

Table 1. Grade of pigment pattern in culture population of black clown fish (Amphiprion percula)

\begin{tabular}{cccc}
\hline \multirow{2}{*}{$\begin{array}{c}\text { Tingkatan } \\
\text { Grade }\end{array}$} & \multicolumn{3}{c}{$\begin{array}{c}\text { Pola pigmen (Ban putih) } \\
\text { Pigment pattern (White band) }\end{array}$} \\
\cline { 2 - 4 } & Kepala (Head) & Badan (Body) & Ekor (Tail) \\
\hline A & +1 & +1 & +1 \\
B & +1 & +1 & -1 \\
C & +1 & +1 & 0 \\
D & +1 & -1 & -1 \\
E & +1 & -1 & +1 \\
\hline
\end{tabular}

Keterangan (Remark): +1: Ban putih sempurna (Perfectly white band)

-1 : Ban putih tidak sempurna (Imperfectly white band)

0 : Ban putih tidak terbentuk (White band not formed)

pada wadah jaring ukuran $100 \mathrm{~cm} \times 100 \mathrm{~cm} \times$ $150 \mathrm{~cm}$. Sebagai kontrol digunakan 1 sampel induk betina dari populasi alam. Berdasarkan peran lingkungannya dilakukan pengamatan parameter kualitas air yang meliputi: suhu, DO, salinitas, $\mathrm{pH}$, dan iluminasi yang diamati pada pagi hari yaitu pukul 07.00 WITA dan sore hari pada pukul 15.30 WITA. Sampel populasi budidaya yang telah dipelihara diambil 2-3 ekor yang dikelompokan berdasarkan 5 tingkatan pola pigmen yang ditemukan (Tabel 1).

Organ sampel yang digunakan pada analisis protein ini adalah otak dan kulit.

\section{Ekstraksi Protein}

Ekstraksi protein dilakukan menurut Darbre (1986), dengan modifikasi penggunaan nitrogen cair untuk mempermudah proses mekanik dalam penggerusan sampel organ. Ekstraksi dilakukan dengan menggunakan larutan buffer ekstrak ( $1 \%$ triton X, $150 \mathrm{mM} \mathrm{NaCl}, 50$ $\mathrm{mM}$ tris $\mathrm{HCl} \mathrm{pH} \mathrm{8).} \mathrm{Pengukuran} \mathrm{kadar} \mathrm{protein}$ dilakukan setelah proses ekstraksi berdasarkan Robyt \& White (1987). Selanjutnya elektroforesis SDS Page dilakukan setelah menyamakan kadar protein seluruh sampel organ. Pewarnaan pada gel menggunakan CBB pada sampel organ kulit dan silver staining pada sampel organ otak.

\section{Analisis Data}

Data dianalisis menurut konfirmasi profil pita yang muncul. Profil pita yang menunjuk- kan polimorfisme dilakukan scoring berdasarkan pola variasi genetik yang muncul dari masing-masing individu di tiap-tiap populasi. Selanjutnya dilakukan UPGMA clustering untuk menentukan hubungan kedekatan jarak antar masing-masing populasi dengan menggunakan software TFPGA (Tools for Population Genetik Analysis).

\section{HASIL DAN BAHASAN}

\section{Peran gen Aim 1 dalam menginduksi pola pigmen}

Hasil isolasi genom DNA dari sampel ikan badut hitam (Amphiprion percula) dengan karakter fenotip berbeda, menunjukkan nilai total antara 49-119 $\mu \mathrm{g} / \mu \mathrm{L}$, pada populasi budidaya tingkatan $\mathrm{A}=73,5 \mu \mathrm{g} / \mu \mathrm{L} ; \mathrm{B}=84$ $\mu \mathrm{g} / \mu \mathrm{L} ; \mathrm{C}=60,67 \mu \mathrm{g} / \mu \mathrm{L} ; \mathrm{D}=101,5 \mu \mathrm{g} / \mu \mathrm{L} ; \mathrm{E}=$ $78,17 \mu \mathrm{g} / \mu \mathrm{L}$, serta pada populasi alam $\hat{0}=$ $84 \mu \mathrm{g} / \mu \mathrm{L} ;$ i $=70 \mu \mathrm{g} / \mu \mathrm{L}$. Dalam penelitian, amplifikasi DNA menggunakan primer yang digunakan untuk mengkode cDNA pada beberapa ikan cichlid Afrika yaitu Aim 1 (Sugie et al., 2004). Primer Aim 1 mampu mengamplifikasi sequence DNA ikan badut hitaM pada kisaran panjang sequence 45 bp (Gambar 2). Hasil amplifikasi DNA yang diekspresikan pada agarose selanjutnya dikonfirmasi dengan memfragmentasi dalam poliacrilamid menggunakan metode SSCP (single strand conformation polymorphism). Berdasarkan hasil fragmentasi SSCP primer Aim 1 (Gambar 3), diketahui bahwa pada populasi budidaya 


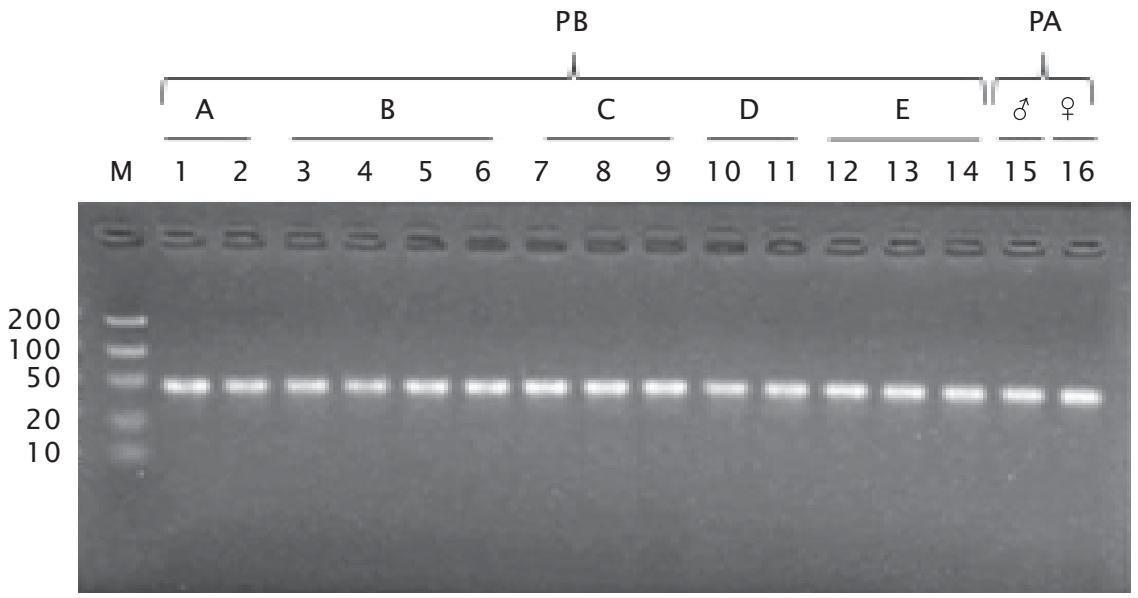

Gambar 2. Hasil amplifikasi primer Aim 1 pada whole genom ikan badut hitam (Amphiprion percula). PA (populasi alam); PB (populasi budidaya); $\mathrm{A}=$ tingkatan pola pigmen 3 ban (kepala, badan, ekor) sempurna; $B=$ tingkatan pola pigmen ban kepala dan badan sempurna, ban ekor tidak sempurna; $\mathrm{C}=$ tingkatan pola pigmen ban kepala dan badan sempurna, ban ekor tidak muncul; $\mathrm{D}=$ tingkatan pola pigmen ban kepala sempurna, ban badan dan ekor tidak sempurna; $\mathrm{E}=$ tingkatan pola pigmen ban kepala dan ekor sempurna, ban badan tidak sempurna; 0 to (populasi alam (F0) jantan dan betina)

Figure 2. The results of amplification the primary Aim 1 on whole genome of blackclown fish (Amphiprion percula), PA (wild type population); PB (cultured population); $A$ = the perfect grade of pigment pattern 3 white band (head, body, tail); $B=$ grade of perfectly head and body pigment pattern imperfectly tail pigment pattern; $C=$ grade of perfectly head and body pigment pattern, tail pigment pattern not formed; $D=$ grade of perfectly head pigment pattern, imperfectly body and tail pigment pattern; $E$ = grade of perfectly head and tail pigment pattern, imperfectly body pigment pattern; 0 o (wild type population (FO) males and females)

memiliki kesamaan pola profil DNA dengan populasi alam (F0 $\&$ + ). Hal ini menunjukkan bahwa kedua populasi (alam dan budidaya) tidak memiliki diferensiasi alel (monomorphik) bila diamplifikasi dengan primer Aim1. Dengan kata lain primer Aim 1 tidak dapat mengekspresikan perbedaan variasi genetik pada kedua populasi tersebut. Berdasarkan hasil fragmentasi, jumlah keseluruhan profil pita yang teramati pada amplicon primer Aim 1 adalah 3 alel. Ketiga alel tersebut memiliki kisaran panjang sequence di bawah $10 \mathrm{bp}$ yang merupakan marker terendah. Sehingga kisaran base pair ketiga alel tidak bisa ditentukan.

Melalui pendekatan secara genetik suatu karakter fenotip akan selalu diturunkan oleh induk pada turunannya. Namun terdapat berbagai macam hal yang menyebabkan adanya penyimpangan karakter fenotip. Melalui kajian gen Aim 1 sebagai salah satu gen yang bertanggung jawab dalam sintesis melanin di mana mutasi dari gen ini menyebabkan hipopigmentasi dengan berbagai variasi fenotip (Sugie et al., 2004) melalui depigmentasi pada sel-sel pigmen melanophore, xanthophore, leukophores dan iridophores (Du \& Fisher, 2002) diketahui bahwa profil fragmentasi gen Aim 1 hasil SSCP (Gambar 3) pada populasi budidaya homolog dengan populasi alam. Hal ini dapat dikatakan bahwa gen Aim 1 bukan merupakan gen target yang memiliki korelasi positif terhadap adanya degeneratif pola pigmen pada ikan badut hitam (Amphiprion percula). Namun hal 

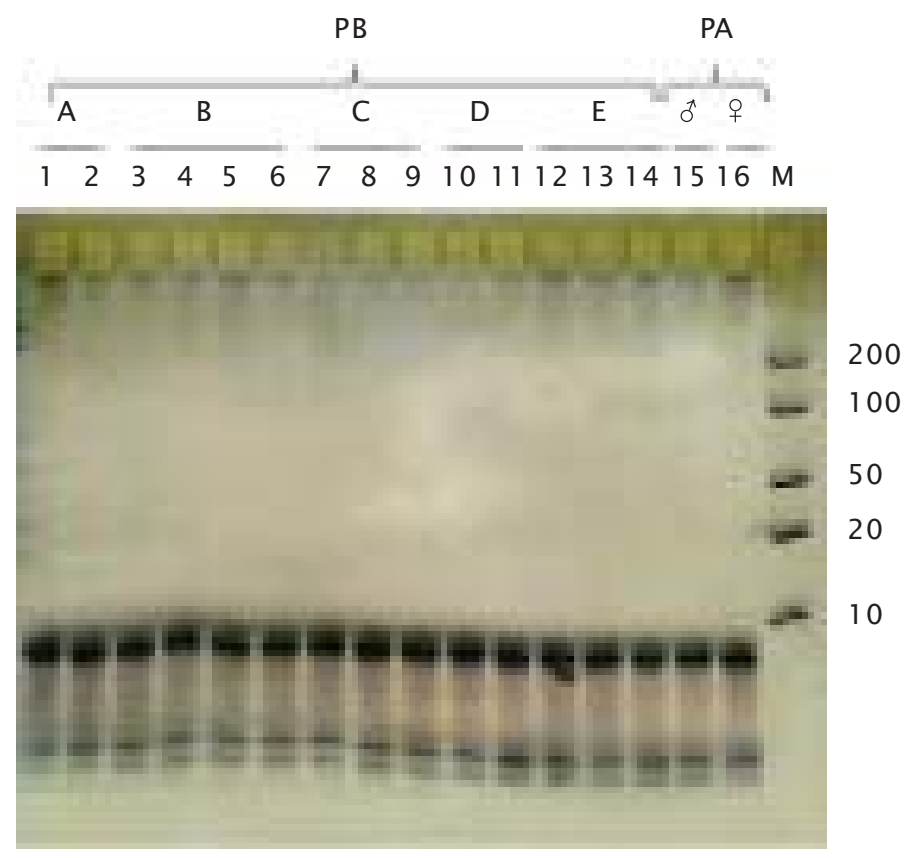

Gambar 3. Konfirmasi hasil PCR primer Aim 1 dengan menggunakan analisis SSCP (Single Strand Confirmation Polimorphism). PA (populasi alam); PB (populasi budidaya); $\mathrm{A}=$ tingkatan pola pigmen 3 ban (kepala, badan, ekor) sempurna; $B$ = tingkatan pola pigmen ban kepala dan badan sempurna, ban ekor tidak sempurna; $\mathrm{C}=$ tingkatan pola pigmen ban kepala dan badan sempurna, ban ekor tidak muncul; $\mathrm{D}=$ tingkatan pola pigmen ban kepala sempurna, ban badan dan ekor tidak sempurna; $E=$ tingkatan pola pigmen ban kepala dan ekor sempurna, ban badan tidak sempurna; $\delta$ o (populasi alam (F0) jantan dan betina)

Figure 3. Confirmation of the PCR product of primer Aim 1 using SSCP analysis (Single Strand Confirmation Polimorphism). PA (wild type population); $P B$ (cultured population); $A$ = the perfect grade of pigment pattern 3 white band (head, body, tail); $B$ = grade of perfectly head and body pigment pattern imperfectly tail pigment pattern; $C$ = grade of perfectly head and body pigment pattern, tail pigment pattern not formed; $D=$ grade of perfectly head pigment pattern, imperfectly body and tail pigment pattern; $E$ = grade of perfectly head and tail pigment pattern, imperfectly body pigment pattern; 0 of (wild type population (FO) males and females)

ini bisa juga terjadi akibat penggunaan primer yang tidak spesifik untuk ikan badut hitam, sehingga tidak menunjukkan hasil yang positif. Sehingga perlu kajian lebih lanjut tentang menggunakan primer yang spesifik untuk ikan badut hitam. Selain itu, perlu pengkajian mengenai ekspresi protein (mRNA) terkait dengan kondisi lingkungan pemeliharaan ikan badut hitam yang dilakukan secara intensif dan terkontrol dengan melalui pengadaptasian yang cukup lama. Suatu sequence DNA yang homolog belum tentu akan menghasilkan ekspresi protein yang sama. Hal tersebut tergantung dari sinyal atau stimulus spesifik yang diterima. Sinyal atau stimulus spesifik yang diterima yang oleh reseptor spesifik akan berdampak terhadap aktivasi suatu mekanisme downstream yang mempengaruhi regulasi transkripsi dan translasi sehingga akan mempengaruhi ekspresi protein yang dihasilkan (Albert et al., 1994). Selain gen Aim 1, terdapat banyak gen yang berhasil diisolasi 
dari beberapa spesies ikan hias air tawar yang mengontrol pola pigmen beberapa di antaranya adalah gen tyrosinase (Boonanuntanasarn et al., 2004), Mitf (microphthalmia-associated transcription factor) (Lister et al., 1999), endothelin receptor b1 (Parichy et al., 2000), dan lain sebagainya. Sejumlah gen yang ditemukan tersebut berperan terhadap perkembangan normal pola pigmen (Odenthal et al., 1996).

\section{Peran Lingkungan terhadap Profil Protein}

Pada benih F1 (populasi budidaya) yang dipelihara dalam kondisi pemeliharaan berbeda yaitu outdoor dan indoor terdapat perbedaan performansi pada pola pigmen yang terbentuk (Gambar 4). Pada benih yang dipelihara secara outdoor memiliki performansi sebaran granula melanosome yang lebih rapat dan lebih banyak sehingga menampakkan performansi yang lebih gelap (Gambar 4 a-d). Terlihat bahwa formasi sebaran granula melanosome banyak mengumpul pada bagian anterior dorsal (Gambar 4c). Sebaliknya benih-benih yang dipelihara secara indoor memiliki performansi sebaran granula melanosome yang lebih sedikit dan jarang dengan penyebaran yang merata pada seluruh bagian tubuh sehingga memberikan performansi yang lebih terang (Gambar 4 e-h). Bila membandingkan kedua performansi pola pigmen khususnya warna hitam (melanophore) yang terbentuk antara benih yang dipelihara secara outdoor maupun indoor, benih-benih yang dipelihara secara outdoor memberikan performasi pola pigmen yang menyerupai dengan pola pigmen pada populasi di alam.

Terkait dengan perbedaan performansi pola pigmen yang muncul, menunjukkan bahwa lingkungan merupakan faktor yang berperan penting dalam menstimulus sintesis dan migrasi sel pigmen khususnya melanophore. Secara umum kisaran parameter kualitas air pemeliharaan yaitu: suhu, DO, salinitas, dan $\mathrm{pH}$ baik pada lingkungan outdoor maupun indoor menunjukkan perbedaan nilai rata-rata yang tidak signifikan (Tabel 2). Pada parameter iluminasi yaitu besarnya intesitas cahaya yang masuk ke dalam perairan menunjukkan perbedaan nilai rata-rata yang sangat signifikan antara benih yang dipelihara secara outdoor maupun indoor. Intensitas cahaya pada yang masuk hingga ke dasar wadah pemeliharaan pada 2 kondisi pemeliharaan berbeda yaitu outdoor dan indoor memiliki perbedaan yang sangat signifikan yaitu sebesar $88,38 \%$ pada pagi hari (07.00 WITA) dan 91,71\% (15.30 WITA). Sedangkan pada permukaan air pemeliharaan memiliki perbedaan sebesar $94,77 \%$ pada pagi hari (07.00 WITA) dan 97,1 9\% pada sore hari (15.30 WITA).

Melalui pendekatan kedua yaitu pengaruh lingkungan dalam menstimulus pola pigmen ikan badut hitam menunjukkan dampak yang cukup positif. Diketahui intensitas cahaya jauh lebih memegang peranan dalam penyebaran migrasi pola pigmen khususnya warna hitam (melanophore). Cahaya yang masuk ke.dalam perairan memberikan pengaruh terhadap dispersi melanophore sehingga memberikan warna lebih gelap pada ikan badut hitam yang dipelihara pada kondisi outdoor dan secara visual memperlihatkan performansi yang menyerupai performansi populasi alam. Namun pada beberapa spesies, keberadaan cahaya memberikan pengaruh yang bertolak belakang yaitu kecenderungan melanophore untuk mengumpul (agregasi) sehingga memberikan performansi yang lebih terang (Wakamatsu, 1978; Oshima et al., 1998). Terkait dengan sifat melanophore yang mampu menyerap cahaya UV (Lin \& Fisher, 2007), perlu mempertimbangkan peranan intensitas cahaya yang mampu menembus hingga ke dasar perairan mengingat tingkah laku ikan badut hitam memiliki kecenderungan berenang di dasar (benthic). Pada masing-masing spesies memiliki kisaran optimum intesitas cahaya (Oshima et al., 1998; Ohta et al., 2003). Pada kisaran intensitas cahaya yang tepat, sel pigmen hitam (melanophore) akan merespons sinyal spesifik dari cahaya yang diterima. Melanophore dapat memberikan respon terhadap cahaya secara langsung maupun tidak langsung. Melanophore merespons secara langsung (light-sensitive melanophore) melalui stimulasi cahaya yang diterima. Melanosome pada light-sensitive melanophore melakukan migrasi baik secara menyebar (dispersal) maupun mengumpul (agregasi). Secara tidak langsung, respons melanophore terjadi melalui sistem endocrine atau neural control (Wakamatsu, 1978). Meskipun sel pigmen diproduksi dari dorsal neural tube, sel harus melalui proses migrasi secara ekstensif untuk dapat mencapai lokasi tujuan. Pada ikan, melanophore bermigrasi secara lateral (di bawah perkembangan epidermis) dan medial (di antara somite dan neural tube). Seiring dengan perkembangan ikan, akumulasi sel 

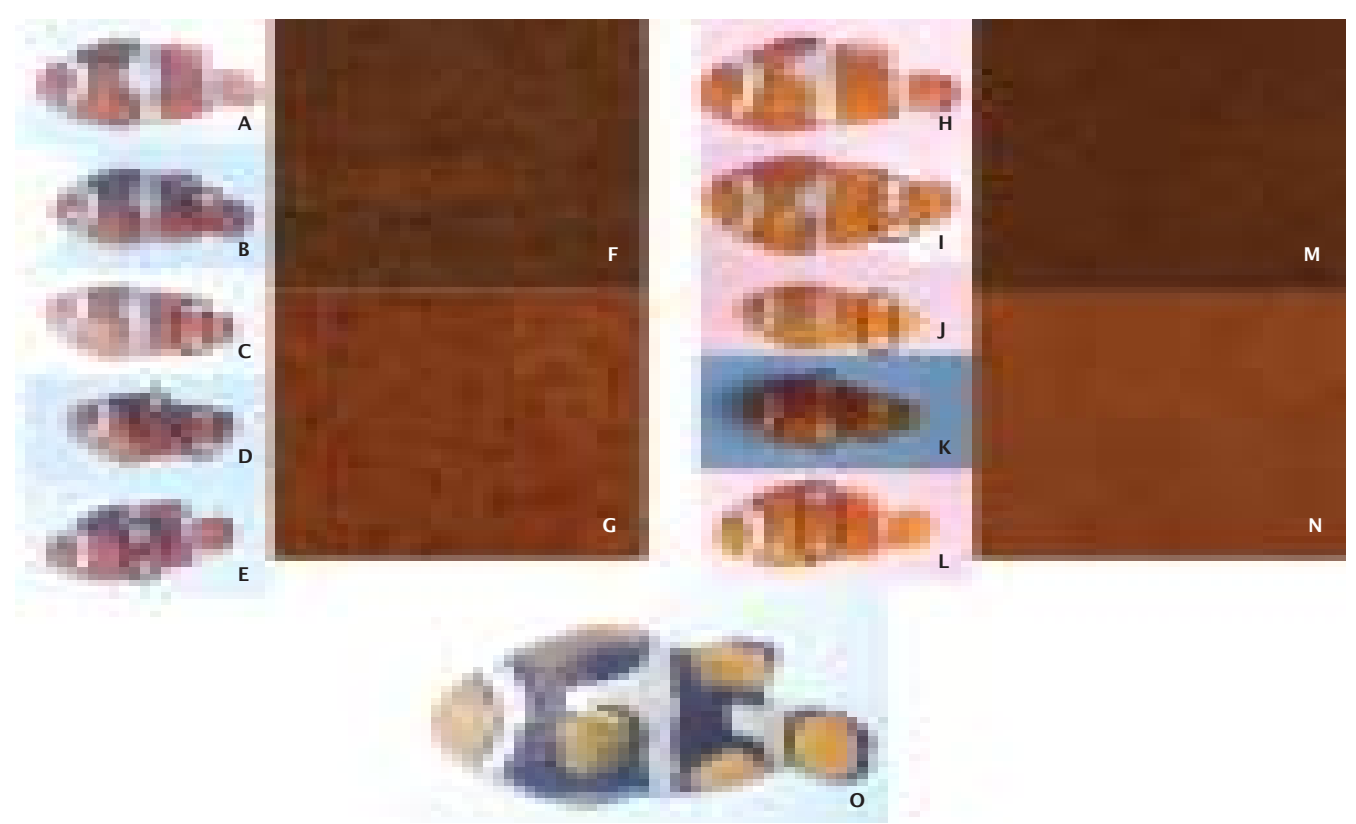

Gambar 4. Performansi pola pigmen ikan badut hitam (Amphiprion percula) selama pemeliharaan. Tingkatan pola pigmen A hingga E populasi budidaya F1 outdoor (A-E), indoor (H-L) $(0,8 \mathrm{x})$, dan populasi alam $(\mathrm{O})$. Formasi sebaran pigmen (melanocyt) pada benih $\mathrm{F} 1 \mathrm{ikan}$ badut hitam (Amphiprion percula) di outdoor bagian sisi anterior dorsal (4X) (F), posterior $(4 \mathrm{x})(\mathrm{G})$ dan indoor bagian sisi anterior dorsal $(4 \mathrm{x})(\mathrm{M})$, posterior $(4 \mathrm{X})(\mathrm{N})$. Dari atas ke bawah (gambar $\mathrm{A}-\mathrm{E}$ dan $\mathrm{H}-\mathrm{L}$ ) menunjukkan tingkatan pola pigmen $\mathrm{A}=$ tingkatan pola pigmen 3 ban (kepala, badan, ekor) sempurna; $\mathrm{B}=$ tingkatan pola pigmen ban kepala dan badan sempurna, ban ekor tidak sempurna; $C=$ tingkatan pola pigmen ban kepala dan badan sempurna, ban ekor tidak muncul; $\mathrm{D}=$ tingkatan pola pigmen ban kepala sempurna, ban badan dan ekor tidak sempurna; $E$ = tingkatan pola pigmen ban kepala dan ekor sempurna, ban badan tidak sempurna

Figure 4. Performance of pigment pattern of black clown fish (Amphiprion percula) during maintenance. Grade of pigment pattern A until E of cultured population F1 in outdoor $(A-E)$, indoor $(H-L)(0.8 x)$, and wild type populations $(O)$. Distribution of pigment formation (melanocyt) in outdoor Fl seed of black clown fish (Amphiprion percula), the anterior dorsal side (4X), posterior $(4 x)(G)$ and dorsal anterior side of indoor $F 1$ seed $(4 x)(M)$, posterior $(4 x)(N)$. From top to bottom (figure A-E and $H-L$ ) shows the grade of pigment pattern $A=$ the perfect grade of pigment pattern 3 white band (head, body, tail); $B=$ grade of perfectly head and body pigment pattern imperfectly tail pigment pattern; $C$ = grade of perfectly head and body pigment pattern, tail pigment pattern not formed; $D=$ grade of perfectly head pigment pattern, imperfectly body and tail pigment pattern; $E$ = grade of perfectly head and tail pigment pattern, imperfectly body pigment pattern

pigmen akan berubah dan perubahan tersebut akan menginduksi perubahan pola warna (Kelsh, 2004).

Hasil konfirmasi secara visual berdasarkan karakter fenotip pada ikan badut hitam, selanjutnya dilakukan ekstraksi protein untuk melihat profil protein pada jaringan otak dan kulit pada populasi budidaya yang dipelihara secara outdoor dan indoor. Hasil ekstraksi protein pada jaringan otak dari ikan badut hitam dengan karakter fenotip yang berbeda yang dipelihara dalam kondisi berbeda yaitu outdoor dan indoor menunjukkan nilai kadar protein berkisar 0,066-0,122 $\mu \mathrm{g} / \mu \mathrm{L}$, sedangkan pada hasil ekstraksi protein jaringan kulit, menun- 
Tabel 2. Parameter kualitas air selama pemeliharaan

Table 2. Water quality parameters during maintenance

\begin{tabular}{lcc}
\hline \multicolumn{1}{c}{$\begin{array}{c}\text { Parameter } \\
\text { Paramet ers }\end{array}$} & $\begin{array}{c}\text { Ruang terbuka } \\
\text { Out door }\end{array}$ & $\begin{array}{c}\text { Ruang tert ut up } \\
\text { Indoor }\end{array}$ \\
\hline Suhu (Temperature) $\left({ }^{\circ} \mathrm{C}\right)$ & $28.42 \pm 0.54$ & $28.28 \pm 0.38$ \\
Do (mg/L) & $6.25 \pm 0.58$ & $5.03 \pm 0.22$ \\
Salinitas (Salinity) & $31.93 \pm 2.33$ & $32.55 \pm 0.72$ \\
$\mathrm{pH}$ & $8.32 \pm 0.04$ & $8.23 \pm 0.06$ \\
Iluminasi (Illumination): & & \\
- Bawah (Bottom) (lux) & $10364.69 \pm 6065.72$ & $209.43 \pm 142.57$ \\
- Permukaan (Surface) (lux) & $3468.50 \pm 2770.01$ & $115.90 \pm 55.26$ \\
\hline
\end{tabular}

jukkan nilai kadar protein berkisar 0,073-0,139 $\mu \mathrm{g} / \mu \mathrm{L}$ (Tabel 3). Tinggi rendahnya nilai kadar protein ini mengindikasikan tinggi rendahnya keberhasilan ekstraksi protein dari jaringan organ.

Berdasarkan hasil analisis SDS Page, terdapat variasi konfirmasi profil pita protein baik pada protein organ otak (Gambar 5) maupun kulit (Gambar 6). Pada konfirmasi profil protein organ otak (Gambar 5), terdapat 2 common alel yang muncul berdasarkan konfirmasi profil protein di semua individu pada masing-masing populasi. Kedua alel tersebut berada pada kisaran berat molekul $61,61 \mathrm{kDa}$ dan 38,82 kDa. Di antara common alel yang muncul, terdapat alel-alel lain yang hanya muncul pada beberapa sampel. Berdasarkan berat molekul common alel, terdapat 4 kelompok alel dengan kisaran berat molekul $>55 \mathrm{kDa}$ (lokus I), 36-55 kDa (lokus II), 24-36 kDa (lokus III), dan < 19 kDa (lokus IV). Pada kelompok I terdiri atas 1 common alel $(61,61$ $\mathrm{kDa}$ ) dengan beberapa alel lain dengan kisaran berat molekul 116,11 kDa; 100,39 kDa; 83,62 kDa; 76,97 kDa; dan 56,83 kDa. Alel-alel lain ini nampaknya hanya merupakan profil protein spesifik yang hanya terekspresi pada beberapa individu tertentu saja. Sehingga keberadaan profil protein tersebut tidak memiliki kaitan terhadap pola pigmen ikan badut hitam.

Kelompok II terdiri atas 1 common alel $(38,82 \mathrm{kDa})$ dengan beberapa alel lain dengan kisaran berat molekul 52,92 kDa; 49,03 kDa; 47,95 kDa; 44,60 kDa; 44,09 kDa; 41,57 kDa; dan 40,26 kDa. Alel dengan kisaran berat molekul 47,95 kDa dan 44,60 kDa hanya terekspresi pada populasi budidaya yang dipelihara outdoor. Sementara itu, pada populasi alam dan populasi budidaya yang dipelihara indoor menunjukkan variasi profil protein yang cukup tinggi. Hal ini menunjukkan adanya peran stimulus dari lingkungan yang bertindak sebagai activator dan inhibitor dalam sintesis protein-protein yang berada pada otak. Adanya cahaya yang diterima oleh sistem syaraf akan mengaktivasi mekanisme downstream mengekspresikan protein tertentu. Namun dengan ketiadaan sinyal atau stimulus dari lingkungan yaitu cahaya, profil protein yang terekspresi menjadi lebih bervariasi.

Kelompok III terdiri atas alel-alel yang hanya terekspresi pada populasi budidaya outdoor tingkatan A-D. Alel-alel tersebut berada pada kisaran berat molekul 30,23 kDa dan 25,73 kDa. Pada grade E populasi budidaya outdoor tidak mengekspresikan alel-alel tersebut. Hal ini menunjukkan bahwa pada tingkatan E populasi budidaya outdoor terdapat suatu blocking mekanisme sehingga profil protein pada berat molekul 30,23 kDa dan 25,73 kDa tidak terekspresi seperti halnya pada populasi budidaya outdoor lainnya. Adanya blocking mekanisme ini mungkin ada kaitannya dengan pola pigmen yang terbentuk mengingat selsel pigmen merupakan derivate dari neuron. Sementara pada populasi alam dan populasi budidaya indoor tidak mengekspresikan profil protein tersebut, karena kondisi pemeliharaan yang berbeda sehingga stimulus dari lingkungan yang diterima juga berbeda.

Pada kelompok IV terdapat 2 alel dengan kisaran berat molekul 17,62 kDa dan 16,46 kDa. Alel dengan berat molekul 16,46 kDa hanya terdapat pada populasi budidaya indoor 
Tabel 3. Kadar protein dan nilai heterosigositas pada masing-masing perlakuan dari jaringan sampel organ otak dan kulit berdasarkan tingkatan pola pigmen

Table 3. The protein content and heterozigosity values for each treatment of brain and skin tissue based on grade of pigment pattern

\begin{tabular}{lcc}
\hline $\begin{array}{c}\text { Kode sampel } \\
\text { Sample code }\end{array}$ & $\begin{array}{c}\text { Kadar protein } \\
\text { Protein content }\end{array}$ & $\begin{array}{c}\text { Nilai het erosigositas } \\
\text { Het erozigoty values }\end{array}$ \\
\hline O.PBO-A & 0.108 & 0 \\
O.PBO-B & 0.091 & 0 \\
O.PBO-C & 0.091 & 0.5 \\
O.PBO-D & 0.080 & 0.667 \\
O.PBO-E & 0.108 & 0.444 \\
O.PBI-A & 0.094 & 0.5 \\
O.PBI-B & 0.066 & 0.667 \\
O.PBI-C & 0.084 & 0.667 \\
O.PBI-D & 0.087 & 0.625 \\
O.PBI-E & 0.086 & 0 \\
O.PA & 0.122 & 0 \\
K.PBO-A & 0.105 & 0.5 \\
K.PBO-B & 0.078 & 0 \\
K.PBO-C & 0.073 & 0.444 \\
K.PBO-D & 0.091 & 0.5 \\
K.PBO-E & 0.087 & 0.667 \\
K.PBI-A & 0.117 & 0.667 \\
K.PBI-B & 0.113 & 0.5 \\
K.PBI-C & 0.081 & 0.5 \\
K.PBI-D & 0.139 & 0.667 \\
K.PBI-E & 0.130 & 0.75 \\
K.PA & 0.083 & 0 \\
\hline
\end{tabular}

\footnotetext{
Keterangan (Remark):

O : Otak (Brain)

$\mathrm{K}$ : Kulit (Skin/integument)

PBO : Populasi budidaya outdoor (Outdoor cultured population)

PBI : Populasi budidaya indoor (Indoor cultured population)

PA : Populasi alam (Wild type population)

A-E : Tingkatan pola pigmen populasi budidaya ikan badut hitam (Grade of pigment pattern of cultured population of black clown fish)
}

tingkatan C-E. Sedangkan pada populasi yang lain memiliki alel dengan berat molekul yang sama yaitu 17,62 kDa. Nampaknya ini terkait dengan karakter fenotip pada ikan badut hitam. Degeneratif pola pigmen yang muncul dengan kondisi pemeliharaan indoor yang membatasi adanya stimulus dari lingkungan menyebabkan adanya ekpresi protein yang menyimpang.
Pada konfirmasi profil protein jaringan kulit (Gambar 6), terdapat 9 common alel yang muncul berdasarkan konfirmasi profil pita protein di semua individu pada masing-masing populasi. Kesembilan alel tersebut berada pada kisaran berat molekul $288 \mathrm{kDa} ; 165,13$ kDa; 139,27 kDa; 72,57 kDa; 57,84 kDa; 42,73 kDa; 36,09 kDa; 33, 13 kDa; 16,86 kDa. Di antara common alel yang muncul, terdapat alel-alel 

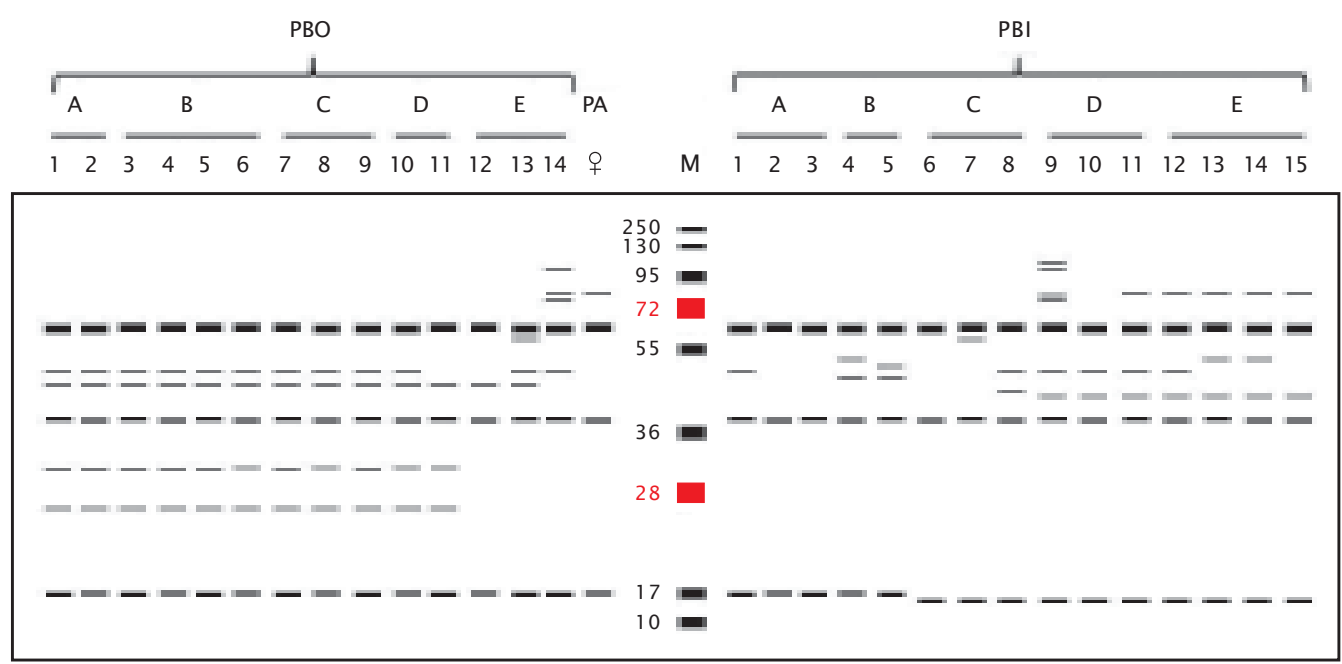

Gambar 5. Konfirmasi pita protein organ otak dengan metode SDS Page. PBO (Populasi budidaya outdoor). PA (Populasi alam). PBI (Populasi budidaya indoor)

Figure 5. Confirmation of protein band of brain tissue by SDS Page method. PBO (Outdoor cultured population). PA (Wild type population). PBI (Indoor cultured population)
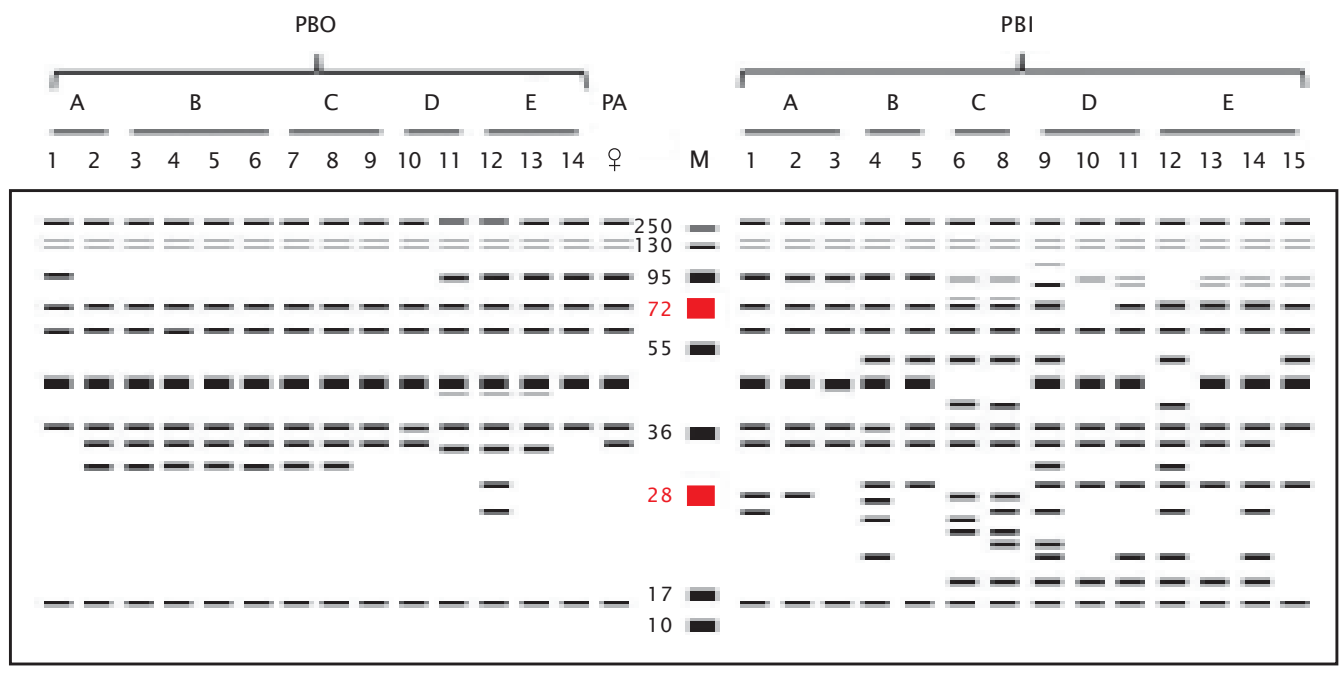

Gambar 6. Konfirmasi pita protein organ kulit dengan metode SDS Page. PBO (Populasi budidaya outdoor). PA (Populasi alam). PBI (Populasi budidaya indoor)

Figure 6. Confirmation of protein band of skin/integument tissue using SDS Page method. PBO (Outdoor cultured population). PA (Wild type population). PBI (Indoor cultured population)

lain yang hanya muncul pada beberapa sampel. Berdasarkan berat molekul common alel, terdapat 6 kelompok alel dengan kisaran berat molekul $>130 \mathrm{kDa}(\mathrm{I}), 55-95 \mathrm{kDa}(\mathrm{II}), 40-$ $55 \mathrm{kDa}$ (III), 30-37 (IV), 17-31 (V), dan < $17 \mathrm{kDa}$
(VI). Pada kelompok I, hanya terdiri atas 3 common alel (288 kDa; 165,13 kDa; 139,27 $\mathrm{kDa}$ ) yang dimiliki seluruh populasi. Sementara pada kelompok II, terdiri 2 common alel $(72,57$ $\mathrm{kDa} ; 57,84 \mathrm{kDa}$ ) dengan beberapa alel lain 
dengan kisaran berat molekul 117,82 kDa; 99,61 kDa; 94,69 kDa; 91,1 8 kDa; 81,24 kDa; dan 76, 16 kDa. Konfirmasi profil pita dengan kisaran berat molekul 99,61 kDa muncul pada sampel-sampel tingkatan $\mathrm{D}$ dan $\mathrm{E}$ pada populasi budidaya pada pemeliharaan outdoor, sampel tingkatan A dan B populasi budidaya pada pemeliharaan indoor dan pada populasi alam. Melihat keterkaitan karakter fenotip antara populasi alam dan budidaya tingkatan A yang dipelihara secara outdoor, alel 99,61 kDa seharusnya juga dimiliki oleh semua tingkatan dari individu populasi budidaya $C$ yang dipelihara secara outdoor. Nampaknya ada beberapa penyimpangan terjadi, namun belum diketahui pasti penyebabnya dan hal ini memerlukan kajian lebih lanjut. Sementara itu, pada karakter fenotip yang mengalami degeneratif pola pigmen (tingkatan C-E) pada populasi budidaya yang dipelihara secara indoor mengekspresikan variasi alel yang cukup banyak (1 17,82 kDa; 94,69 kDa; 91,18 kDa; 81,24 kDa; 76,16 kDa). Nampaknya semakin banyak degeneratif pola pigmen yang muncul pada masing-masing individu menyebabkan munculnya variasi alel yang tidak diinginkan.

Pada alel-alel kelompok III, terdiri atas 1 common alel $(42,73 \mathrm{kDa})$ dan beberapa alel lain dengan kisaran berat molekul 47,70 kDa dan 39,52 kDa. Nampak common alel pada berat molekul $42,73 \mathrm{kDa}$ yang semestinya terekspresi pada seluruh populasi tidak terekspresi pada beberapa individu dalam populasi budidaya dengan pemeliharaan indoor yaitu pada seluruh individu tingkatan C dan 1 individu tingkatan E. Terkait dengan tidak terekspresinya alel tersebut, dimungkinkan akibat kondisi jaringan sampel dan proses isolasi protein pada jaringan yang tidak cukup optimum. Selain itu, protein memiliki sifat yang sangat rentan terhadap degradasi. Pada alel dengan kisaran 47,70 kDa muncul pada individu populasi budidaya pada kondisi pemeliharaan indoor yang memiliki tingkatan $B$ hingga $E$, sedangkan pada alel dengan kisaran berat molekul 39,52 kDa hanya muncul pada individu tingkatan $\mathrm{C}$ dan $\mathrm{E}$ dengan kondisi pemeliharaan indoor. Nampaknya, kedua alel 47,70 kDa dan 39,52 kDa hanya terekspresi pada individu yang memiliki degeneratif pola pigmen dengan kondisi pemeliharaan indoor. Terekspresinya kedua alel tersebut sangat berkaitan erat dengan kondisi lingkungan pemeliharaan ikan badut hitam. Sehingga dapat dikatakan bahwa alel ini menunjukkan korelasi positif terhadap adanya degeneratif pola pigmen pada ikan badut hitam.

Pada alel kelompok IV, terdiri atas $2 \mathrm{com}$ mon alel $(36,09 \mathrm{kDa}, 33,13 \mathrm{kDa})$ dan alel lain yang memiliki kisaran berat molekul 30,54 kDa. Pada beberapa individu yaitu tingkatan A dan E pada populasi budidaya dengan pemeliharaan outdoor, tingkatan E pada populasi budidaya dengan pemeliharaan indoor tidak menunjukkan adanya ekspresi common alel dengan berat molekul 33,13 kDa. Seperti halnya yang terjadi pada common alel dengan berat molekul 42,73 kDa (kelompok III) bahwa mungkin disebabkan akibat kondisi jaringan sampel dan proses isolasi protein pada jaringan yang tidak cukup optimum. Selain itu, terkait juga dengan sifat protein yang sangat rentan terhadap degradasi.

Pada alel kelompok $V$ tidak terdapat common alel, hanya terdiri atas alel-alel memiliki ekspresi yang sangat bervariasi dengan kisaran berat molekul 29,10 kDa; 27,68 kDa; 26,39 kDa; 24,98 kDa; 23,31 kDa; 22,13 kDa; $21 \mathrm{kDa}$; dan 19,48 kDa. Konfirmasi alel-alel tersebut lebih banyak terekspresi pada populasi budidaya yang dipelihara indoor. Pada populasi budidaya yang dipelihara outdoor dan populasi alam tidak menunjukkan ekspresi alel-alel tersebut kecuali 1 individu tingkatan E dalam populasi yang dipelihara outdoor. Terkait dengan ekspresi pola pigmen pada populasi budidaya yang dipelihara outdoor lebih menyerupai populasi hasil alam, maka dapat dikatakan bahwa alel-alel pada kelompok $\mathrm{V}$ ini merupakan alel-alel yang tidak terekspresi. Nampaknya telah terjadi agregasi alel-alel dengan berat molekul yang lebih tinggi. Pada kelompok VI hanya terdiri atas 1 common alel dengan kisaran berat molekul $16,86 \mathrm{kDa}$.

Berdasarkan variasi genetik yang muncul pada hasil konfirmasi profil protein jaringan otak dan kulit melalui metode SDS Page, dilanjutkan dengan scoring untuk menentukan level polimorfisme di antara masingmasing populasi dan UPGMA clustering dengan menggunakan TFPGA (Tools for Population Genetic Analysis). Hasil scoring pada konfirmasi profil protein otak dan kulit ikan badut hitam menunjukkan nilai heterosigositas yang bervariasi pada masing-masing tingkatan pola pigmen baik yang dipelihara secara outdoor maupun indoor (Tabel 3). Berdasarkan nilai scoring, dilanjutkan dengan UPGMA cluster- 


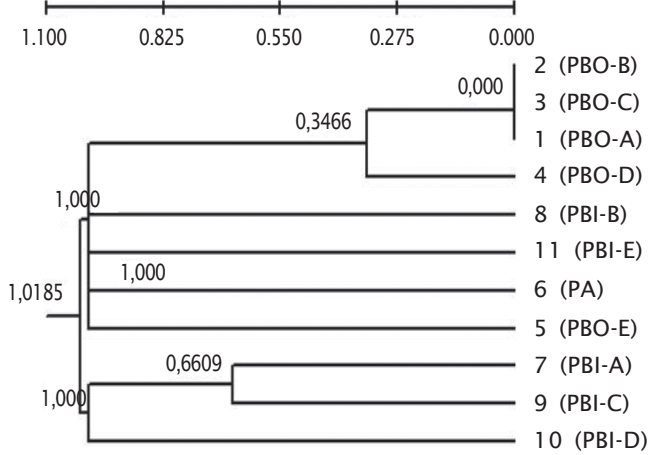

a

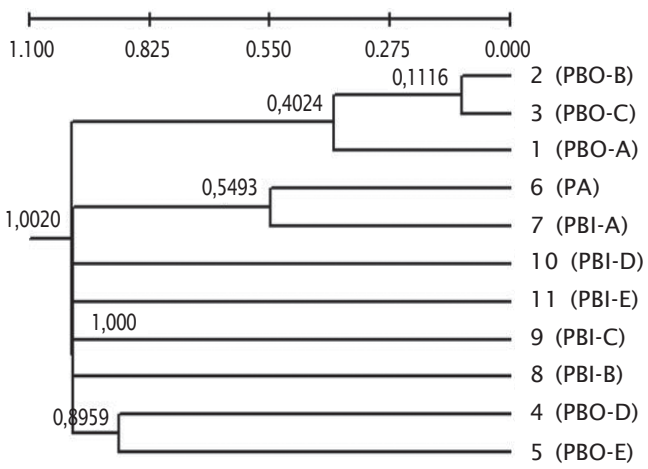

b

Gambar 7. Dendogram hasil UPGA clustering berdasarkan profil pita protein otak (a) dan kulit (b) hasil konfirmasi menggunakan SDS Page. PBO (Populasi budidaya outdoor). PA (Populasi alam). PBI (Populasi budidaya indoor)

Figure 7. Dendogram of UPGA clustering based on protein band profile of brain (a) and skin/ integument (b) using SDS Page. PBO (Outdoor cultured population). PA (Wild type population). $\mathrm{PBI}$ (Indoor cultured population)

ing (Gambar 7) pada profil pita protein organ otak dan kulit. Hasil clustering menunjukkan adanya sedikit perbedaan dendogram yang terbentuk antara populasi alam dengan populasi budidaya yang dipelihara secara outdoor dan indoor. Pada dendogram profil protein organ otak terdapat 3 kelompok besar berdasarkan jarak kedekatan hubungan yang terbentuk. Kelompok I yaitu tingkatan A, B, C yang memiliki kedekatan tingkatan $D$ populasi budidaya outdoor, selanjutnya kelompok II yaitu tingkatan B, E populasi budidaya indoor, populasi alam dan tingkatan E populasi budidaya outdoor yang saling memiliki jarak kedekatan hubungan yang sama, dan kelompok terakhir yaitu kelompok III yaitu tingkatan A dan $C$ yang memiliki kedekatan hubungan dengan tingkatan D populasi budidaya indoor (Gambar 7a). Berdasarkan kelompok yang terbentuk pada dendogram, kelompok II dan III memiliki hubungan yang cukup dekat. Hal ini menunjukkan bahwa faktor lingkungan memberikan stimulus yang mempengaruhi sistem syaraf sehingga berpengaruh terhadap profil protein yang terbentuk. Dan jika melihat kedekatan hubungan tingkatan E pada populasi budidaya outdoor dengan populasi alam dan tingkatan $B$ dan $C$ populasi budidaya indoor, karakter fenotip nampaknya ikut juga memberikan pengaruh terhadap respons stimulus yang diberikan dari lingkungan. Pada pola degeneratif pigmen tertentu, menunjukkan adanya blocking mekanisme sehingga stimulus yang diterima dari lingkungan tidak dapat direspons yang berdampak terhadap ekspresi profil protein otak.

Pada dendogram profil protein kulit, terdapat 4 kelompok berdasarkan jarak kedekatan hubungan yang terbentuk yaitu kelompok I yaitu tingkatan B dan $C$ yang memiliki kedekatan hubungan dengan tingkatan A populasi budidaya outdoor, kelompok Il yaitu populasi alam yang memiliki kedekatan hubungan dengan tingkatan A populasi budidaya indoor, kelompok III yaitu tingkatan B, C, D, dan E pada populasi budidaya indoor yang saling memiliki jarak kedekatan hubungan yang sama, dan kelompok IV yaitu tingkatan D populasi budidaya outdoor yang memiliki kedekatan hubungan dengan tingkatan $\mathrm{E}$ populasi budidaya outdoor. Dari kelompok yang terbentuk, terdapat korelasi positif antara profil protein kulit dengan karakter fenotip yang terbentuk. Berdasarkan dendogram, juga diketahui bahwa antara populasi alam yang dipelihara secara indoor dengan populasi budidaya tingkatan A yang juga dipelihara secara indoor memiliki jarak kedekatan hubungan yang jauh lebih erat apabila dibandingkan dengan populasi budidaya tingkatan A yang dipelihara secara outdoor walaupun secara visual memiliki performasi pola pigmen yang lebih menyerupai populasi alam. Hal ini menunjukkan bahwa proteinprotein pada kulit sampel PA dan PBI-A memiliki karakter protein yang sama. Nampaknya hal tersebut terkait dengan kondisi pemeliharaan 
yang sama pula yaitu indoor walaupun dengan performansi visual yang berbeda, yaitu populasi alam lebih gelap sedangkan populasi budidaya tingkatan A indoor lebih pucat, yang membuktikan bahwa sinyal atau stimulus dari lingkungan (faktor eksternal) yang bersifat spesifik dalam hal ini adalah cahaya memiliki peran penting dalam mengontrol mekanisme downstream dalam tubuh ikan badut hitam yang berdampak terhadap ekspresi protein kulit yang dihasilkan. Ketiadaan sinyal atau stimulus spesifik akan menghambat protein spesifik untuk disintesis (Alberts et al., 1994).

Terkait dengan kedekatan hubungan antara profil protein organ otak dan kulit pada populasi alam dan populasi budidaya yang dipelihara dalam kondisi indoor, nampaknya peran otak sebagai sistem syaraf memiliki hubungan yang saling terkait dengan organ kulit sebagai fate sel pigmen. Hal ini mengindikasikan bahwa sinyal dari lingkungan eksternal memberikan stimulus oleh sistem syaraf yang berpengaruh terhadap profil protein kulit, mengingat sel-sel pigmen merupakan derivate dari sistem syaraf (neural), kedua dendogram baik pada profil protein otak dan kulit menunjukkan adanya peranan faktor lingkungan terhadap terbentuknya pola pigmen. Terkait dengan peran sistem syaraf maka erat sekali hubungannya dengan sistem endokrin. Dalam sistem endokrin diketahui terdapat melanin concentrating hormone dan $\alpha$ melanin stimulating hormone yang masing-masing berperan dalam mengontrol agregasi (mengumpul) dan dispersi (menyebar) melanophore pada epidermis (Oshima et al., 1986). Seperti disebutkan pada alenia sebelumnya, migrasi melanophore pada ikan badut hitam populasi budidaya yang dipelihara secara outdoor dapat terjadi secara langsung akibat respons dari lingkungan yaitu cahaya. Namun melihat adanya kaitan profil protein otak dan kulit, migrasi yang terjadi pada ikan badut hitam yang dipelihara secara outdoor juga dipengaruhi oleh sistem endokrin. Perubahan jumlah sel pigmen disebabkan adanya sinyal-sinyal spesifik sebagai respons terhadap perubahan lingkungan sekitar, antara lain perubahan kondisi warna lingkungan habitat hidup, intensitas cahaya (Karlsson, 2001) yang melalui media komunikasi akan diterima oleh sel syaraf dan hormon pada aliran darah dan untuk kemudian akan ditangkap oleh reseptor spesifik di permukaan sel pigmen. Sebagai respons dari sinyal-sinyal tersebut, granula sel pigmen dapat melakukan translokasi (migrasi) secara menyebar (dispersal) yang menginduksi warna menjadi lebih kontras (gelap) dan mengumpul/terkonsentrasi (agregasi) pada daerah perinuclear sehingga indeks refraktori warna ikan berubah menjadi nampak lebih cerah (lightening). Kemampuan migrasi granula melanin (melanosome) dalam sistem integument melanophore dikontrol secara otomatik oleh sistem syaraf (nervous) atau peptide hormone (Nery \& Castrucci, 1997).

\section{KESIMPULAN}

Gen Aiml diketahui mampu mengamplifikasi whole genom ikan badut hitam (Amphiprion percula) dengan target sequence 45 bp, namun gen Aim 1 bukan merupakan gen target yang memiliki korelasi positif terhadap degeneratif pola pigmen yang muncul pada populasi budidaya ikan badut hitam (Amphiprion percula). Cahaya merupakan faktor eksternal diketahui memiliki peran penting dalam menstimulus sistem neuron untuk mengaktifkan mekanisme downstream yang berdampak dalam profil protein yang disintesis dan sekaligus memberikan pengaruh terhadap migrasi melanophore secara dispersal yang memberikan performansi lebih gelap pada benih-benih populasi budidaya.

\section{DAFTAR ACUAN}

Alberts, B., Bray, D., Lewis, J., Raff, M., Roberts, K., \& Watson, J.D. 1994. Molecular Biology of The Cell Third edition: Cell Signaling. Garland Publishing. USA, 1294 pp.

Boonanuntanasarn, S., Yoshizaki, G., Iwai, K., \& Takeuchi, T. 2004. Molecular Cloning, Gene Expression in Albino Mutants and Gene Knockdown Studies of Tyrosinase mRNA in Rainbow Trout. Pigment Cell Research, 17: 413-421.

Darbre, A. 1986. Analytical Methods. In Practical Protein Chemistry: Handbook. John Willey and Sons. New York, p. 227-335.

Du, J. \& Fisher, E. 2002. Identification of Aim-1 as The Underwhite Mouse Mutant and Its Transcriptional Regulation by Mitf. The Journal of Biological Chemistry, 277(1): 402406.

Gonzales, J.L.H. \& Uy, J.A.C. 2009. Alternative Mating Strategies May Favor The Persistence of A Genetikally Based Colour Polymorphism In A Pentamorphic Fish. Animal Behavior, 77: 1,187-1,194. 
Gouveia, L., Rema, P., Pereira, O., \& Empis, J. 2003. Colouring Ornamental Fish (Cyprinus carpio and Carassius auratus) With Microalgal Biomass. Aquaculture Nutrition. Blackwell Publishing Ltd, p. 125-129.

Hofreiter, M. \& Schöneberg, T. 2010. The Genetik and Evolutionary Basis of Colour Variation in Vertebrates. Review Article. Cellular and Molecular Life Sciences. Vol. 67. Spingerlink. p. 2,591-2,603.

Karlsson, A. 2001. Signaling For Color Change In Melanophore And A Bioseneor Application. Linköpings University Medical Dissertations. Sweden, 53 pp.

Kelsh, R.N. 2004. Review: Pigment Gene Focus. Genetic And Evolution of Pigment Patterns In Fish. Pigment Cell Res. Vol. 17. Blackwell Munksgaard, p. 326-336.

Kelsh, R.N., Brand, M., Jiang, Y.J., Heisenberg, C.P., Lin, S., Haffter, P., Odenthal, J., Mullins, M.C., Eeden, F.J.M.V., Seiki, M.F., Granato, M., Hammerschmidt, M., Kane, D.A., Warga, R.M., Beuchie, D., Vogelsang, L., \& Volhard, C.N. 1996. Zebrafish Pigmentation Mutation and The Processes of Neural Crest Development. Development, 123: 369-389.

Korzan, W.J., Robinson, R.R., Zhao, S., \& Fernald, R.D. 2008. Color Change As Potential Behavioral Strategy. Hormones and Behavior. Vol. 54. Elsevier Inc, p. 463-470.

Lin, J.Y. \& Fisher, D.E. 2007. Melanocyte Biology and Skin Pigmentation. Nature, 445: 843-850.

Lister, J.A., Robertson, C.P., Lepage, T., Johnson, S.L., \& Raible, D.W. 1999. Nacre Encodes A Zebrafish Microphthalmia-Related Protein That Regulates Neural Crest-Derived Pigment Cell Fate. Development, 126: 3,757-3,767.

Nery, L.E.M. \& Castrucci, A.M.L. 1997. Pigment Cell Signalling For Physiological Color Change. Comparative Biochemistry And
Physiology. Vol. 118A No. 4. Elsevier Science Inc, p. 1,135-1,144.

Odenthal, J., Rossnagel, K., Haffter, P., Kelsh, R.N., Vogelsang, E., Brand, M., F.J.M.V. Eeden, Seiki, M.F., Granato, M., Hammerschmidt, M., Heisenberg, C.P., Jiang, Y.J., Kane, D.A., Mullins, M.C., \& Volhard, C.N. 1996. Mutations Affecting Xanthopore Pigmentation in The Zebrafish Danio rerio. Development, 123: 391-398.

Ohta, T., Suzuki, Y., \& Shimazaki, M. 2003. The Nature of The Response of Scale Melanophores of The Teleost Fish, Pseudorasbora parva, to Light. The Bulletin of Aichi Univercity of Education 52. Natural Science, p. 29-34.

Oshima, N., Kasukawa, H., Fujii, R. Wilkes, B.C., Hruby, V.J., \& Hadley, M.E. 1986. Action of Melanin-Concentrating Hormone (MCH) on Teleost Chromatophores. General And Comparative Endocrinology. Vol 64. Academic Press Inc, p. 381-388.

Oshima, N., Nakata, E., Ohta, M., \& Kamagata, S. 1998. Light-Induced Pigment Aggregation in Xanthophores of The Medaka, Oryzias latipes. Pigment Cell Research, 11:362367.

Parichy, D.M., Mellgren, E.M., \& Rawls, J.F. 2000. Mutational Analysis of Endothelin Receptor b1 (rose) during Neural Crest and Pigment Pattern Development in The Zebrafish Danio rerio. Developmental Biology, 227: 294-306.

Robyt, J.F. \& White, B.J. 1987. Biochemical Technique, Theory and Practice. Brook/Cole Publ. Co, 234 pp.

Sugie, A., Terai, Y., Ota, R., \& Okada, N. 2004. The Evolution of Genes for Pigmentation in African Cichlid Fishes. Gene. Vol. 343. Elsevier, p. 337-346.

Wakamatsu, Y. 1978. Light-Sensitive Fish Melanophore in Culture. Journal of Experimental Zoology, 204(2): 299-304. 